Журнал«Герстективита інновації наукиљ

(Серія «Гедагогіка», Серія «Гиихологія», Серія «Медицинв»

№(6) 2022

УДК 796.015: 814/374 (477)

https://doi.org/10.52058/2786-4952-2022-1(6)-122-131

Голяка Сергій Кіндратович кандидат біологічних наук, доцент, Херсонський державний університет, вул. Університетська, 27, м. Херсон, 73000, тел.: (0552) 32-67-65, https://orcid.org/0000-0001-6805-584X

Кольцова Ольга Сергіївна кандидат педагогічних наук, доцент, Херсонський державний університет, вул. Університетська, 27, м. Херсон, 73000, тел.: (0552) 32-67-65, https://orcid.org/0000-0002-4817-7812

Коваль Вікторія Юріївна кандидат педагогічних наук, доцент, Херсонський державний університет, вул. Університетська, 27, м. Херсон, 73000, тел.: (0552) 32-67-65, https://orcid.org/0000-0003-0550-8631

Кучеренко Андрій Олександрович магістр 3 фізичного виховання, Херсонський державний університет, вул. Університетська, 27, м. Херсон, 73000, тел.: (0552) 32-67-65

\title{
ЕФЕКТИВНІСТЬ МЕТОДИКИ ПІДВИЩЕННЯ ФІЗИЧНОЇ ПІДГОТОВЛЕНОСТІ БОРЦІВ-САМБІСТІВ В УМОВАХ СЕКЦІЙНОӤ ПОЗАШКІЛЬНОЇ РОБОТИ
}

Анотація. Належний розвиток фізичної підготовленості сучасних підлітків та юнаків можливий лише за умови тривалої, систематичної та цілеспрямованої підготовки, яка може здійснюватися під час класно-урочної, позаурочної, а також позашкільної форми фізичного виховання.

Рівень фізичної підготовленості останнім часом погіршується в учнівської молоді, і це визначає передумови щодо перегляду існуючої системи фізичного виховання, пошук новітніх засобів занять фізичним вправами, створення цікавих позашкільних спортивних секцій для підвищення мотивації учнів до систематичних занять фізичною культурою. Одним із ефективним засобів позашкільної секційної роботи для сприяння підвищенню фізичної підготовленості підростаючого покоління $є$ заняття у секції бойового самбо.

Успішність у багатьох видах спорту багато в чому залежить від якісної фізичної підготовки, і цей процес відбувається за трьома взаємозалежними напрямками - виховання, навчання та підвищення функціональних можливостей організму борців-самбістів, реалізується на практиці через загальну та спеціальну фізичну підготовку, далі через технічну, тактичну, морально-вольову та теоретичну підготовку цих спортсменів.

Фізичну підготовку борців-самбістів фахівці розглядають як складний, досить багатосторонній процес цілісного та доцільного використання різних за 
сукупністю факторів, тобто засобів та методів, а також інші умови, які забезпечують цілеспрямований розвиток борців у бойовому самбо i необхідний ступінь їх готовності до значних спортивних досягнень. При цьому раціональність побудови їх навчально-тренувального процесу буде визначатися певною спрямованістю формування оптимальної структури щодо змагальної діяльності, а також враховувати індивідуальні особливості.

Важливим методом використання засобів фізичної підготовки $є$ коловий метод тренування з використанням елементів ігрового методу в їх поєднанні, що у свою чергу урізноманітнює засоби здійснення фізичної підготовки підлітків у бойовому самбо, підвищує їх зацікавленість до занять і сприяє більш ефективній фізичній підготовці юних спортсменів.

Ключові слова: фізична підготовленість, бойове самбо, позашкільні спортивні секції.

Holiaka Serhii Kindratovych Ph.D. of Biological sciences, Associate Professor, Kherson State University, Universytetska St., 27, Kherson, 73000, tel.: (0552) 32-67-65, https://orcid.org/0000-0001-6805-584X

Koltsova Olha Serhiivna Ph.D. of Pedagogic Sciences, Associate Professor, Kherson State University, Universytetska St., 27, Kherson, 73000, tel.: (0552) 32-67-65, https://orcid.org/0000-0002-4817-7812

Koval Viktoriia Yuriivna Ph.D. of Pedagogic Sciences, Associate Professor, Kherson State University, Universytetska St., 27, Kherson, 73000, tel.: (0552) 32-67-65, https://orcid.org/0000-0003-0550-8631

Kucherenko Andrii Oleksandrovych Master's Degree Physical Education, Kherson State University, Universytetska St., 27, Kherson, 73000, tel.: (0552) 32-67-65

\section{EFFICIENCY OF METHODS OF INCREASING PHYSICAL PREPAREDNESS OF SAMBIST WRESTLERS IN THE CONDITIONS OF SECTIONAL EXTRACURRICULAR WORK}

Abstract. Proper development of physical fitness of adolescents and young people is possible only with long-term, systematic and purposeful training, which can be carried out during classroom, extracurricular and forms of physical education.

The level of physical fitness has recently deteriorated among students, and this determines the prerequisites for reviewing the existing system of physical education, finding new means of exercise, creating interesting extracurricular sports sections to increase students' motivation for regular exercise. One of the effective means of extracurricular sectional work to help improve the physical fitness of the younger generation is training in the combat sambo section. 
Success in many sports largely depends on quality physical training and this process takes place in three interdependent areas - education, training and enhancement of the body of sambo wrestlers, implemented in practice through general and special physical training, then through technical, tactical, moral and volitional and theoretical training of these athletes.

Physical training of sambo wrestlers is considered by experts as a complex, multifaceted process of holistic and appropriate use of various factors, tools and methods, as well as other conditions that ensure purposeful development of wrestlers in combat sambo and the necessary degree of readiness for significant sporting achievements. In this case, the rationality of the construction of their educational and training process will be determined by a certain direction of formation of the optimal structure for competitive activities, as well as take into account individual characteristics.

An important method of using physical training is the circular method of training using elements of the game method in their combination, which in turn diversifies the means of physical training of adolescents in combat sambo, increases their interest in training and promotes more effective physical training of young athletes.

Keywords: physical fitness, combat sambo, extracurricular sports sections.

Постановка проблеми. Належний розвиток фізичної підготовленості сучасних підлітків та юнаків можливий лише за умови тривалої, систематичної та цілеспрямованої підготовки, яка може здійснюватися під час класноурочної, позаурочної, а також позашкільної форми фізичного виховання [3].

Як відомо, рівень фізичної підготовленості остатнім часом погіршився у учнівської молоді, і це визначає передумови щодо перегляду існуючої системи фізичного виховання, здійснювати пошук новітніх засобів занять фізичним вправами, а також створення цікавих позашкільних спортивних секцій, які б дозволили підвищувати мотивацію учнів до систематичних занять фізичними вправами. I одним із ефективним засобів позашкільної секційної роботи, який сприяв підвищенню фізичної підготовленості підростаючого покоління $\epsilon$ заняття у секції бойового самбо.

Аналіз останніх досліджень і публікацій. Вивченню рівня фізичної підготовленості підростаючого покоління, зокрема під час занять бойовим самбо присвячено роботи багатьох вчених.

Питанням підвищення рівня фізичної підготовленості борців-самбістів присвячені роботи Александрова Ю. В., Кучеренка А. О., Троня Р.А., Ільїна В.М., Бицюри Р.В., Шабето М.Ф. та інших $[1,3,5,6]$.

Однак, питання розробки та впровадження ефективних методик вдосконалення рівня фізичної підготовленості старших підлітків під час занять у позашкільних секціях з бойового самбо розроблені не в повному обсязі і потребують додаткової уваги.

Мета статті - дослідити вплив експериментальної методики тренувальних занять бойовим самбо на рівень загальної та спеціальної фізичної підготовленості старших підлітків. 
Виклад основного матеріалу. Дослідження фізичної підготовленості юних спортсменів, які займалися у позашкільній секції з бойового самбо базувалася в м.Херсон, в гімназії №20. У дослідженні прийняли участь 16 борців-самбістів віком від 14 до 16 років, які були віднесені до групи спеціальної базової підготовки першого і другого року навчання. Зі всіх самбістів було 12 спортсменів I-го юнацького розряду та 4 - II-го юнацького розряду. Тренери-інструктори Кучеренко А.О. та Гринько О.М.[3].

Визначення рівня загальної (ЗФП) та спеціальної фізичної підготовленості (СФП) у групі борців-самбістів ми здійснювали двічі: після переходу їх до групи спеціалізованої підготовки (вересень 2020 року) і після переходу їх другого року навчання в групі спеціалізованої підготовки.

Для визначення ефективності впровадження методу колового тренування (МКТ) з метою підвищення рівня фізичної підготовленості нами було створено однорідні за підготовленістю групи: експериментальна (ЕГ) (7 осіб) та контрольна (КГ) (9 осіб). У цих групах обстеження нами двічі проводилося тестування їх фізичної підготовленості: перше на початку вересня 2020 року та друге обстеження після 2,5 місяців впровадження МКТ із елементами ігрової діяльності наближеної до змагальних дій.

Нами розроблялася i вдосконалювалася застосування МКТ для забезпечення ефективної фізичної підготовки борців. В ЕГ основним методом тренувань передбачався МКТ із елементами змагального та ігрового методу, а в КГ обстежуваних - основним методом був лише МКТ [3].

Як ми відмічали раніше (Кучеренко А.О, 2020), у ЕГ на початку нового навчально-тренувального року після проходження адаптації після закінчення перехідного етапу попереднього року тренувань (вересень-жовтень) протягом 6-ти тижнів застосовувався МКТ, що був спрямований на підготовку самбіста, і що передбачав розвиток спритності, силової витривалості, а 3 другої половини жовтня був додатково спрямований на розвиток СФП. Головним показником для цих вправ були інтенсивність роботи досліджуваних, межі їх індивідуального пульсу характерного для тренування під час виконання завдань і відновлення під час відпочинку [3].

Колові тренування 3 підвищення фізичної підготовленості нами застосовувалися по вівторках і четвергах, тобто два рази на тиждень. Станції складалися із вправ на тренажерах, iз застосуванням обтяжень, iз застосуванням ваги власного тіла (підтягування на перекладині, віджимання на брусах тощо).

На цьому етапі ми також до основного МКТ включали елементи ігрового методу тренування. Він передбачав використання певної кількості спеціалізованих рухливих ігор, які сприяли підвищенню СФП. Зокрема використовували ігри в торкання, ті що блокують захоплення, атакуючі захоплення, на витіснення, на перетягування, ігри зі збереженням рівноваги тощо [3].

На початку першого етапу (перші 3 тижні - 6 занять), коли ми визначили максимальні навантаження у кожного обстежуваного, робота на станціях вже 
створювалася за певною кількістю повторів, в основному, із різними обтяженнями (без чітких тимчасових інтервалів, але в рамках раунду). Вага різних обтяжень на станціях підбиралася для кожного спортсмена індивідуально. Відпочинок між зміною станцій становив 1 хвилину.

Після кожного кола проводилися вправи на розслаблення 2 хв і починали друге коло. Протягом першого тижня необхідно було виконувати по три кола, а протягом другого - по чотири кола.

У другій половині (протягом наступних 3-х тижнів - 3 тренування) першого етапу робота на станціях вже змінилася, ми стали застосовувати чіткі часові інтервали близько 1,5 хв 3 1,5 хв відпочинку між станціями. Повтори у виконанні вправ на кожній станції обстежувані робили свою певну індивідуальну кількість разів, але щоб межі ЧСС знаходилися в І-й зоні - 140160 уд/хв. Контролювалося відновлення спортсменів-самбістів за 1 хв відпочинку.

На наступному етапі підготовки у ЕГ протягом першої половини жовтняпершої половини листопада 2020 року (4 тижні) проводили колові тренування, але цього разу вони бути спрямовані на розвиток специфічних для бойового самбо фізичних здібностей самбістів (два рази на тиждень). Різні станції складалися 3 фізичних вправ із боксерськими грушами, із власною вагою, легкими обтяженнями, вправ на скакалці, ігрових сутичок між суперниками. Робота на станціях була в чітко дозованих часових інтервалах - 1,5-2 хв. На деяких станціях передбачалося дотримання техніки виконання вправ, а це вимагало підвищених вимог до координації рухів, пам'яті, уважності та вольових зусиль.

Визначення рівня фізичної підготовленості борців-самбістів ми здійснювали за загальноприйнятими тестами 3 фізичної підготовки за рекомендаціями навчальних програм 3 бойового самбо (Є.Н. Велієв та ін.) [2], 3 посібника Л.П.Сергієнка, 2001 [4]. Використовували тести: біг на 100 м, крос на 3000 м, човниковий біг $10 \times 10$ м, згинання та розгинання рук в упорі лежачи, стрибок в довжину з місця, лежачи на спині піднімання тулуба в сід за 30 с. Для оцінки СФП використовували тести: виконання ударів по боксерській груші руками, виконання ударів по боксерській груші ногою, перекиди вперед-назад за 30 с, забігання приставним кроком навколо рук 10 разів.

Розглянемо зміни у показниках ЗФП борців-самбістів на двох етапах обстеження. 3 даних таблиці 1. видно, що на I етапі обстеження, коли застосовували запропоновану методику, середній показник бігу на 100 м у самбістів ЕГ становив 13,53 $\pm 0,3$ с, а вже на II етапі цей показник становив $13,44 \pm 0,2$ с. Різниця становила $0,7 \%$ при достовірності різниці $\mathrm{t}=0,25, \mathrm{p} \geq 0,05$. Далі розглянемо результати тестування бігу на 100 м в борців-самбістів КГ.

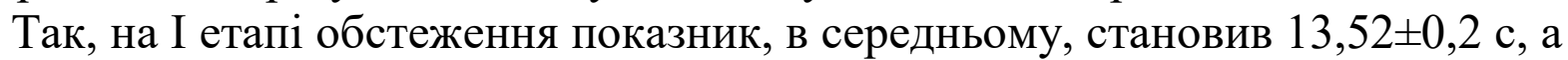
на II етапі цей показник підвищився на $0,3 \%$ до показника $13,48 \pm 0,3$ с. Відмінності у показниках бігу на 100 м на I та II етапах обстеження виявилися не достовірними $(\mathrm{t}=0,25, \mathrm{p} \geq 0,05)$. 
Далі розглянемо результати виконання нормативу з кросу на 3000 м у обох групах обстеження. Так, з даних таблиці видно, що в ЕГ борців-самбістів на I етапі обстеження показник кросового бігу на 3000 м становив, в середньому, $10,50,60 \pm 9,2$ хв, c, а вже на II етапі обстеження ми спостерігали підвищення показника на рівні $1,3 \%$ до величини $10,45,25 \pm 8,6$ хв $(\mathrm{t}=0,41, \mathrm{p} \geq 0,05)$. У КГ борців-самбістів ми спостерігаємо наступні результати: під час I етапу

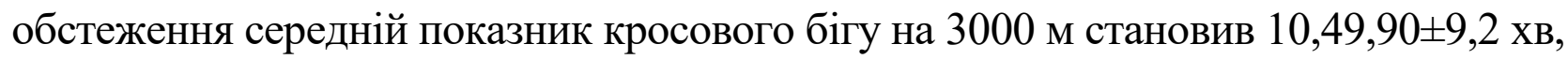
с, тоді як на II етапі ми спостерігаємо покращення показника бігу на 0,4\% до

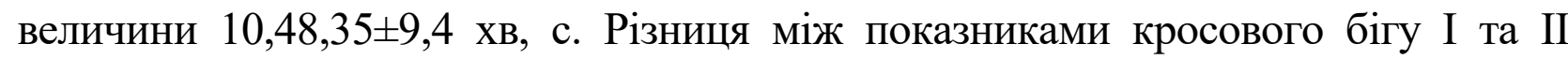
етапів обстеження виявилася не достовірною $(\mathrm{t}=0,12, \mathrm{p} \geq 0,05)$.

Таблиия 1.

Середні показники ЗФП самбістів на I та II етапах дослідження

\begin{tabular}{|c|c|c|c|c|}
\hline Групи/Тести & Вересень 2020 року & Листопад 2020 року & Достовірність & Різниця,\% \\
\hline \multicolumn{5}{|c|}{ Біг на 100 м, с } \\
\hline $\mathrm{E} \Gamma$ & $13,53 \pm 0,3$ & $13,44 \pm 0,2$ & 0,25 & 0,7 \\
\hline КГ & $13,52 \pm 0,2$ & $13,48 \pm 0,3$ & 0,11 & 0,3 \\
\hline \multicolumn{5}{|c|}{ Крос на 3000 м, хв.с } \\
\hline $\mathrm{E \Gamma}$ & $10,50,60 \pm 9,2$ & $10,45,25 \pm 8,6$ & 0,41 & 1,3 \\
\hline КГ & $10,49,90 \pm 9,2$ & $10,48,35 \pm 9,4$ & 0,12 & 0,4 \\
\hline \multicolumn{5}{|c|}{ Човниковий біг $10 \times 10$ м, с } \\
\hline $\mathrm{E} \Gamma$ & $24,3 \pm 0,4$ & $23,9 \pm 0,3$ & 0,8 & 1,6 \\
\hline КГ & $24,5 \pm 0,5$ & $24,4 \pm 0,4$ & 0,16 & 0,4 \\
\hline \multicolumn{5}{|c|}{ Згинання та розгинання рук в упорі лежачи, рази } \\
\hline $\mathrm{E} \Gamma$ & $40,9 \pm 1,1$ & $44,4 \pm 1,1$ & 2,24 & 8,6 \\
\hline КГ & $41,6 \pm 1,2$ & $42,2 \pm 1,2$ & 0,36 & 1,4 \\
\hline \multicolumn{5}{|c|}{ Стрибок в довжину з місця, см } \\
\hline $\mathrm{E} \Gamma$ & $185,4 \pm 3,4$ & $189,8 \pm 3,6$ & 0,89 & 2,4 \\
\hline КГ & $187,0 \pm 4,0$ & $187,2 \pm 4,0$ & 0,04 & 0,1 \\
\hline \multicolumn{5}{|c|}{ Лежачи на спині піднімання тулуба в сід за 30 с } \\
\hline $\mathrm{E} \Gamma$ & $40,2 \pm 1,3$ & $43,2 \pm 1,2$ & 1,69 & 9,9 \\
\hline КГ & $39,4 \pm 1,2$ & $40,8 \pm 1,3$ & 0,83 & 3,5 \\
\hline
\end{tabular}

Наступною вправою за допомогою ми оцінювали рівень ЗФП борцівсамбістів був тест «Човниковий біг $10 \times 10$ м». 3 даних таблиці 1 видно, що на I етапі обстеження середній показник становив $24,3 \pm 0,4$ с, тоді як на II етапі цей показник покращився на 1,6\% до показника $23,9 \pm 0,3$ с. Достовірність різниці становила $\mathrm{t}=0,8, \mathrm{p} \geq 0,05$. У КГ борців-самбістів середній показник вправи

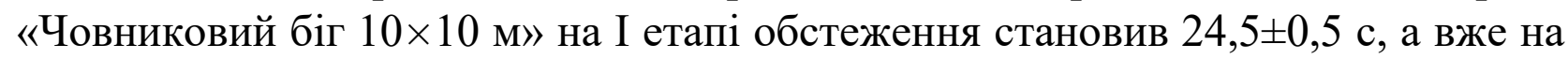

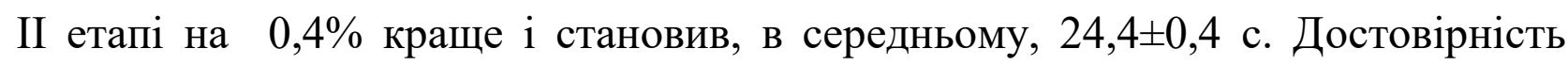
різниці при цьому становила $\mathrm{t}=0,8, \mathrm{p} \geq 0,05$.

Отже, можемо зробити певне заключення, що за період дії експерименту нами не виявлено достовірні різниці у показниках у бігових вправах у групах обстежуваних борців-самбістів.

Розглянемо далі детальніше середні показники виконання самбістами 
вправ «Згинання та розгинання рук в упорі лежачи». Результати представлені у таблиці 1. На I етапі обстеження середній показник виконання цієї вправи виявився відносно вищим у КГ самбістів і становив, в середньому, 41,6 $\pm 1,2$

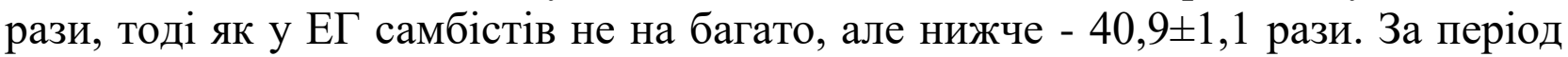
впровадження методики підвищення рівня фізичної підготовленості у ЕГ самбістів середній показник підвищився на 8,6\% до величини 44,4 $\pm 1,1$ рази. А у КГ борців-самбістів теж середній показник за період між двома обстеженнями підвищився, але величина підвищення становила лише 1,4\% до середнього показника 42,2 $\pm 1,2$ рази. При обробці отриманих результатів за допомогою критерію Стьюдента достовірні різниці між показниками першого та другого етапів обстеження лише у ЕГ обстежуваних $(\mathrm{t}=2,24$, $\mathrm{p} \leq 0,05)($ Табл.1.).

Далі розглянемо показники розвитку швидкісно-силових якостей, які ми визначали за результатами виконання стрибка в довжину 3 місця у групах обстежуваних. На I етапі обстеження середній показник стрибка в довжину 3

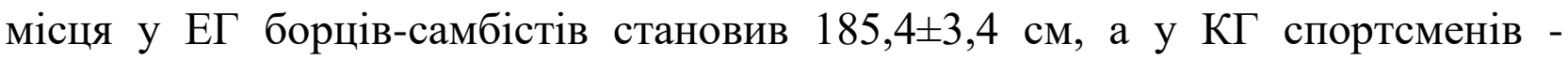
$187,0 \pm 4,0$ см. Під час II етапу обстеження ми спостерігаємо приріст показника стрибка в довжину 3 місця у наших групах обстеження: у ЕГ на 2,4\% до середнього показника $189,8 \pm 3,6$ см, у КГ на 0,1 \% до середнього показника $187,2 \pm 4,0$ см. Статистичний аналіз отриманих показників стрибка в довжину 3 місця не дозволив нам встановити достовірність різниць даних I та II етапу обстеження окремо у групах $(\mathrm{t}=0,04-$ $0,89, \mathrm{p} \geq 0,05)$.

I остання вправа, за допомогою якої ми визначали рівень ЗФП борцівсамбістів на обох етапах обстеження була вправа «Лежачи на спині піднімання тулуба в сід за 30 с». Видно, що на I етапі обстеження середній показник розвитку швидкісно-силової витривалості у ЕГ самбістів становив, в середньому 40,2 $\pm 1,3$ разів, а у КГ - 39,4 $\pm 1,2$ разів. Під час II етапу обстеження показник виконання цієї вправи покращився у борців-самбістів обох груп. Так, у ЕГ самбістів середній показник виконання цієї вправи зріс на 9,9\% і становив, в середньому, 43,2 $\pm 1,2$ рази, але показники між собою достовірно не відрізнялися $(\mathrm{t}=1,69, \mathrm{p} \geq 0,05)$. У КГ борців-самбістів середній показник вправи «Лежачи на спині піднімання тулуба в сід за 30 с», під час I етапу обстеження покращився на $3,5 \%$ до середнього показника 40,8 $\pm 1,3$ рази $(\mathrm{t}=0,83, \mathrm{p} \geq 0,05)$.

Також нами передбачено визначення рівня СФП у групах борців-самбістів на початку та наприкінці експериментального дослідження. Дані дослідження представлені у таблиці 2. 
Таблиия 2

Середні показники СФП самбістів на I та II етапах обстеження

\begin{tabular}{|c|c|c|c|c|}
\hline Групи/Тести & Вересень 2020 року & Листопад 2020 року & Достовірність & Різниця,\% \\
\hline \multicolumn{5}{|c|}{ Виконання ударів по боксерській груші руками, рази } \\
\hline ЕГ & $151,8 \pm 1,3$ & $156,0 \pm 1,3$ & 2,28 & 2,8 \\
\hline КГ & $153,0 \pm 1,3$ & $153,8 \pm 1,2$ & 0,45 & 0,5 \\
\hline \multicolumn{5}{|c|}{ Виконання ударів по боксерській груші ногою, рази } \\
\hline ЕГ & $35,9 \pm 0,4$ & $37,0 \pm 0,5$ & 1,72 & 3,1 \\
\hline КГ & $35,7 \pm 0,4$ & $36,6 \pm 0,4$ & 1,61 & 2,5 \\
\hline Перекиди вперед-назад за 30 с, рази \\
\hline ЕГ & $23,4 \pm 0,3$ & $24,8 \pm 0,3$ & 3,33 & 6,0 \\
\hline КГ & $23,8 \pm 0,3$ & $24,6 \pm 0,2$ & 2,22 & 3,4 \\
\hline \multicolumn{5}{|l|}{ Забігання приставним кроком навколо рук 10 разів, с } \\
\hline ЕГ & $16,6 \pm 0,3$ & $15,8 \pm 0,2$ & 2,22 & 4,8 \\
\hline КГ & $16,2 \pm 0,3$ & $15,7 \pm 0,2$ & 1,39 & 3,1 \\
\hline
\end{tabular}

Розглянемо результати здійснення вправи «Виконання ударів по боксерській груші руками» у групах обстеження. На I етапі дослідження середній показник виконання цієї вправи у ЕГ обстежуваних становив $151,8 \pm 1,3$ рази, а вже під час II етапу цей показник покращився на $2,8 \%$ i становив, в середньому, $156,0 \pm 1,3$ рази, що достовірно відрізнявся від показника I етапу обстеження $(\mathrm{t}=2,28, \mathrm{p} \leq 0,05)$. У КГ обстежуваних ми також спостерігаємо приріст показника виконання цієї вправи під час II етапу обстеження на $0,5 \%$ з $153,0 \pm 1,3$ рази I етапу обстеження до $153,8 \pm 1,2$ рази під час II етапу обстеження, але ці показники достовірно між собою не відрізнялися $(\mathrm{t}=0,45, \mathrm{p} \geq 0,05)$.

Далі розглянемо середні показники здійснення вправи «Виконання ударів по боксерській груші ногою» у групах обстеження. На I етапі відносно кращими результатами характеризувалися самбісти ЕГ, і в них цей показник, в середньому, становив $35,9 \pm 0,4$ рази, тоді як у борців-самбістів КГ середній показник виконання цієї вправ становив, в середньому, $35,7 \pm 0,4$ рази. За період дії експериментального дослідження ми спостерігаємо зростання показників виконання цієї вправи у обох групах обстеження. Так, у ЕГ цей показник підвищився на $3,1 \%$ до величини $37,0 \pm 0,5$ рази, а у КГ і обстежуваних підвищення показника спостерігалося на рівні $2,5 \%$ до величини $36,6 \pm 0,4$ рази. Статистичний аналіз отриманих результатів не дозволив стверджувати про наявність достовірних різниць показників I та II етапів обстеження окремо у ЕГ та КГ обстеження ( $\mathrm{t}=1,61-1,72, \mathrm{p} \geq 0,05)($ Табл.2).

В таблиці 2. представлені також дані виконання тестів СФП борцівсамбістів «Перекиди вперед-назад за 30 с» та «Забігання приставним кроком навколо рук 10 разів». Розглянемо спочатку результати виконання тестування вправи «Перекиди вперед-назад за 30 с» на обох етапах обстеження у наших група самбістів. На I етапі обстеження середній показник виконання цієї вправи становив $23,4 \pm 0,3$ рази у ЕГ, тоді як у КГ, він становив, в середньому, $23,8 \pm 0,3$ рази. Наприкінці дослідження ми спостерігаємо приріст показника 
виконання цієї вправи у обстежуваних борців-самбістів обох груп. Так, у борців-самбістів ЕГ середній показник підвищився на 6,0\% до величини $24,8 \pm 0,3$ рази, а КГ борців-самбістів підвищення на 3,4\% до величини 24,6 $\pm 0,2$ рази. При цьому достовірність різниці між показниками виконання цієї вправи I та II етапів обстеження спостерігалася у обох групах $(\mathrm{t}=2,22-3,33$, $\mathrm{p} \leq 0,05-0,01)$ (Табл.2).

I остання вправа за допомогою, якої ми оцінювали рівень СФП у групах самбістів. На I етапі середній показник виконання вправи «Забігання приставним кроком навколо рук 10 разів» у ЕГ самбістів становив $16,6 \pm 0,3$ с, тоді як у КГ борців-самбістів середній становив 16,2 $\pm 0,3$ с. На II етапі обстеження ми спостерігаємо приріст показника у обох групах обстеження: у ЕГ на 4,8\%, у КГ борців-самбістів на 3,1\%. Середній показник у спортсменів ЕГ становив $15,8 \pm 0,2$ с, а у спортсменів КГ - 15,7 $\pm 0,2$ с.

Статистичний аналіз за допомогою критерію Стьюдента дозволив отримати достовірні різниці між показниками I та II етапу дослідження виконання цієї вправи лише у ЕГ обстежуваних ( $\mathrm{t}=2,22, \mathrm{p} \leq 0,05)$ (Табл. 2.).

Висновки. Здійснивши порівняльну характеристику отриманих середніх показників фізичної підготовленості борців-самбістів можемо відмітити, що за всіма тестами у обох групах обстеження виявлена позитивна динаміка змін показників, особливо чітко подібна тенденція спостерігається у експериментальній групі самбістів (на 0,7\%-9,9\%). Встановлено, що середні показники «Згинання та розгинання рук в упорі лежачи», «Виконання ударів по боксерській груші руками», «Забігання приставним кроком навколо рук 10 разів» борців-самбістів ЕГ покращилися на достовірні величини, ніж аналогічні показники борців-самбістів КГ. Середні показники тесту «Перекиди вперед-назад за 30 с» на II етапі у обох групах достовірно відрізнялися від показників I етапу тестування.

\section{Лimepamypa:}

1. Александров Ю. В. Підвищення ефективності процесу тренування юних самбістів завдяки використанню вправ швидкісно-силової спрямованості [Електронний ресурс]. Режим доступу : https://sportpedagogy.org.ua/html/journal/2008-04/08ajvspo.pdf

2. Велієв Е.Н. Бойове самбо. Навчальна програма для ДЮСШ. Київ, 2017. 65 с.

3. Кучеренко А. О. Контроль та оцінка фізичної підготовленості старших підлітків в умовах позашкільної секції з бойового самбо : кваліфікаційна робота на здобуття ступеня вищої освіти «магістр» ; наук. керівник к.б.н., доц. С. К. Голяка. Херсон : ХДУ, 2020. 58 с. - Режим доступу: http://eKhSUIR.kspu.edu/123456789/12577

4. Сергієнко Л.П. Тестування рухових здібностей школярів: Навчальний посібник. К.: Олімпійська література, 2001. 360 с.

5. Тронь Р.А., Ільён В.М., Бицюра Р.В. Контроль фізичної підготовленості кваліфікованих спортсменів, які спеціалізуються у бойовому самбо // Педагогіка, психологія та медико-біологічні проблеми фізичного виховання і спорту. - 2013. - № 10 - C. 74-77. doi:10.6084/m9.figshare.775334

6. Шабето М.Ф. Боевое самбо. Самозащчита безоружного против палки, ножа, пістолета. Мн.: Современное слово, 2004. 448 с. 


\section{References:}

1.Aleksandrov, Yu.V. (2008). Pidvyschennia efektyvnosti procesu trenuvannia yunykh sambistiv zavdiaky vykorystannyu vprav shvydkisno-sylovoii spriamovanosti [Improving the efficiency of the training process of young sambo wrestlers through the use of speed-strength exercises].Elektonnyi resurs URL: https://sportpedagogy.org.ua/html/journal/2008-04/08ajvspo.pdf [in Ukrainian].

2. Veliyev, E.N. (2017). Boyove sambo. Navchalna programa dlya DYuSSh [Sambo fights. Curriculum for CYSS]. Kyiv, [in Ukrainian].

3. Kucherenko, A.O. (2020). Kontrol ta ocinka fizychnoyi pidgotovlenosti starshykh pidlitkiv $\mathrm{v}$ umovakh pozashkilnoii sekcyi z boyovogo sambo [Monitoring and assessment of older teenagers' physical training in the out-of-school section of combat sambo]. Kvalifikaciyna robota na zdobuttya stupenia vuschoyi osvity «magistr»; nauk.kerivnyk k.b.n., doc. S.K.Holiaka qualification work for the degree of "master"; Science. Head Ph.D., Assoc. SK Holiaka. Kherson : KhSU, [in Ukrainian] URL: http://eKhSUIR.kspu.edu/123456789/12577

4. Sergiyenko, L.P. (2001). Yestuvannya rukhovykh zdibnosteyi shkolyiriv [Testing of motor abilities of schoolchildren]. navchalnyi posibnyk. Kyiv, Olympic literature. [in Ukrainian].

5. Tron, R.A., Ilyin, V.M. \& Bycyura, R.V. (2013). Kontrol fizychnoyi pidgotovlenosti kvalifikovanykh sportsmeniv, yaki specializuyutcya u boyovomy sambo [Control of physical fitness of qualified athletes who specialize in combat sambo] Pedagogika, psykhologiya ta medyko-biologichni problemy fizychnogo vykhovannya i sportu - Pedagogy, psychology and medical and biological problems of physical education and sports, 10. 74-77 [in Ukrainian]. doi:10.6084/m9.figshare.775334

6. Shabeto, M.F. (2004). Boyevoye sambo. Samozaschyta bezorujnogo protiv palki, noja, pistoleta [Combat Sambo. Self-defense of an unarmed person against a stick, knife, gun]. Mn: Sovremennoye slovo [in Russian] 